\title{
IN VITRO STUDY ON RELEASE OF BIOACTIVE ANTIMICROBIAL COMPOUNDS FROM DAIRY PRODUCTS BY CERTAIN PROMISING PROBIOTIC LACTOBACILLUS STRAINS
}

\author{
DEBAPRIYA MOHANTY1*, MANISH RANJAN SAINI², SWATI MOHAPATRA ${ }^{1}$ \\ 1Department of Microbiology, OUAT, Bhubaneswar-3, Odisha, ${ }^{2}$ Institute of Pesticide Formulation Technology, Gurgaon, Haryana, India \\ Email: debapriyam.h@gmail.com
}

Received: 20 Aug 2016 Revised and Accepted: 14 Feb 2017

\section{ABSTRACT}

Objective: The antimicrobial activity and Probiotic properties of Lactobacillus species were evaluated. The antimicrobial compound of potent antimicrobial probiotic Lactobacillus was purified by column chromatography and its nature and stability were determined.

Methods: This investigation was performed with few Lactobacillus strains of ATCC and MTCC along with certain strains isolated from different dairy sources. They were evaluated for their probiotics properties (acid tolerance, bile tolerance, bile salt hydrolase activity, cell autoaggregation, cell surface hydrophobicity and haemolytic behaviour). Agar well diffusion method was used to screen their potency to release bioactive compound against several pathogens. This potent antimicrobial compound was purified by chromatography as well as its molecular mass was estimated by following SDS-PAGE. Finally, the stability of the compound was determined against various ranges of temperature and $\mathrm{pH}$.

Results: Among all Lactobacillus strains, R1 was found to be a potent probiotic strain as well as cell free supernatant (CFS) of R1 showed more strong antagonistic effect against most of the pathogens. Carbohydrate fermentation and physiological characterization of strain R1 matched with Lactobacillus fermentum as per Bergey's manual of systematic bacteriology. The molecular mass of the purified fraction was estimated at approximately $25 \mathrm{kDa}$ and could be stable after heat treatment of $100{ }^{\circ} \mathrm{C}$ for $30 \mathrm{~min}$ and pH range of 4.5-7.0

Conclusion: R1 showed highest antimicrobial activity while it has been found as Lactobacillus fermentum. It is due to the release of a bioactive compound having a molecular mass of $25 \mathrm{kDa}$.

Keywords: Lactobacillus species, Probiotic properties, Antimicrobial compound, Purification

(C) 2017 The Authors. Published by Innovare Academic Sciences Pvt Ltd. This is an open access article under the CC BY license (http://creativecommons.org/licenses/by/4. 0/) DOI: http://dx.doi.org/10.22159/ijpps.2017v9i4.12006

\section{INTRODUCTION}

Probiotic can be defined as living microorganisms that bring nutraceutical benefits to the consumer's health apart from their whole nutritional value after being consumed in a certain number. They have been found to be clinically effective in maintaining the balance of gastrointestinal microbiota to improve health conditions [1]. As per the guideline established by the Joint FAO/WHO (2002) expert panel, the basic parameters for the screening of potentially valuable probiotic strains mainly include functional, safety as well as physiological criteria [2]. A list of characteristics such as tolerance to low $\mathrm{pH}$, bile salt, should have the ability of adherence to human intestinal lining and colonization on mucosal surfaces are explained as functional criteria whereas the ability to inhibit wide range of pathogens by producing antimicrobial substances; immunomodulation; antioxidant; cholesterol metabolism are documented as physiological criteria for screening a potential probiotic strain [3].

Lactobacillus species are also widely used as potential probiotic strains and have a long history of safe use. They are regarded as non-pathogenic and safe microorganisms. Lactic acid bacteria (LAB) also produce antimicrobial substances, such as organic acids, fatty free acids, ammonia, hydrogen peroxide, bio surfactant and lowmolecular-weight antibacterial peptides known to be bacteriocins that inhibit both gram-positive and gram-negative enteric pathogens $[4,5]$. Bacteriocins generally exert their antimicrobial action by interfering with the cell wall or the membrane of target organisms, either by inhibiting cell wall biosynthesis or causing pore formation, subsequently resulting in death. The incorporation of bacteriocins as a bio-preservative ingredient into model food systems has been studied extensively and has been shown to be effective in the control of pathogenic microorganisms [6, 7]. It can be considered as an alternative approach to medical therapy. Here, in our study excellent probiotic Lactobacillus fermentum has been isolated which showed an antimicrobial effect against certain pathogenic strains. The antimicrobial characteristics of Lactobacillus fermentum R1 indicates its possible use in starter cultures for traditional fermented foods as a means of improving the hygiene and safety of the food products. The partially purified inhibiting substance is most active at low $\mathrm{pH}$ values and retains its activity with an increase in temperature. This suits various food and pharmaceutical production processes.

\section{MATERIALS AND METHODS}

\section{Bacterial strains and culture condition}

This study was performed with certain Lactobacillus strains ( $L$. planterum MTCC 1407, L. rhamnosus MTCC 1408, L. casei MTCC 1423, L. delbrucii lectis MTCC 911, L. casei ATCC 9595) directly collected from both ATCC (USA) and MTCC (Chandigarh, India). Again, several dairy products (milk, yogurt, cheese) were also collected from rural regions of Odisha to isolate more Lactobacillus strains. One $\mathrm{ml}$ of sample was tenfold serially diluted in $0.89 \%$ of the normal saline solution and pour plated on MRS agar (Hi-media, India Pvt. Ltd.). For preliminary identification of Lactobacillus species, the pure cultures were again screened as per Bergey's Manual. It mainly includes Gram's reaction, spore formation, catalase.

Screening of Lactobacillus species for their probiotic properties

\section{$A$. Acid and bile salt tolerance}

Acid and bile tolerance of all Lactobacillus species were evaluated in MRS broth by adjusting its $\mathrm{pH}$ at different values ( 2 and 3 ) and supplementing bile salts at the concentrations of $0.3 \%$ and $0.6 \%$ (w/v) (HiMedia, India Pvt. Ltd.) in a separate experiment. Then $1 \mathrm{ml}$ of inoculums were taken from all the samples at $0 \mathrm{~h}, 1 \mathrm{~h}$ and $2 \mathrm{~h}$ and serially diluted up to $10^{-7}$ and poured in MRS agar plates and incubated for $24-48 \mathrm{~h}$ at $37^{\circ} \mathrm{C}$. The colonies appeared on plates after incubation were considered as acid tolerant and bile tolerant and were counted to determine the percentage of acid and bile tolerance $[8,9]$. Each experiment was carried out in triplicate. 


\section{$B$. Bile salt hydrolase activity of sample}

A direct plate assay method was employed for detection of bile salt hydrolase (Bsh) activity. Bsh activity was examined by streaking overnight grown a culture of strain on MRS agar containing $0.5 \%$ $(\mathrm{w} / \mathrm{v})$ bile (sodium cholate) (Hi-media, India Pvt. Ltd.) and $0.37 \mathrm{~g} / \mathrm{l}$ of $\mathrm{CaCl}_{2}$. Then the plates were sealed with parafilm and incubated anaerobically at $37{ }^{\circ} \mathrm{C}$ for $3-4 \mathrm{~d}$. Bsh activity was indicated by deposition of hydrolyzed product in and around the colonies [8].

\section{Cell aggregation assay}

The freshly grown cultures were harvested by centrifugation at $8000 \mathrm{rpm}$ for $10 \mathrm{~min}$ to collect their supernatants (step1). The pellet was washed and re-suspended in equal volume of PBS (phosphate buffer saline) to an absorbance of 0.5 at $600 \mathrm{~nm}\left(\mathrm{~A}_{1}\right)$. The suspensions were distributed in 4 microcentrifuge tubes as $2 \mathrm{ml}$ in each and centrifuged at $8000 \mathrm{rpm}$ for $10 \mathrm{~min}$, and the pellets were resuspended in $2 \mathrm{ml}$ of broth removed at step 1 and incubated at 37 ${ }^{\circ} \mathrm{C}$ for $2 \mathrm{~h} .1 \mathrm{ml}$ of the upper part was removed after incubation time, and absorbance was taken at $600 \mathrm{~nm}\left(\mathrm{~A}_{0}\right)$ [9]. The auto aggregation percentage was calculated as:

$$
\text { Autoaggregation }(\%)=\left(1-\mathrm{A}_{1} / \mathrm{A}_{0}\right) \times 100
$$

\section{$D$. Cell surface hydrophobicity assay}

The bacterial cells grown in MRS broth at $37{ }^{\circ} \mathrm{C}$ for $18 \mathrm{~h}$ were centrifuged, and the cell pellets were washed and resuspended with equal volume of phosphate urea magnesium (PUM) buffer, and the absorbance was adjusted to OD 0.7 at $600 \mathrm{~nm}\left(\mathrm{~A}_{1}\right)$. Lactobacilli cell suspension $(3.0 \mathrm{ml})$ and xylene $(1.0 \mathrm{ml})$ were mixed by using vortex and incubated at $37^{\circ} \mathrm{C}$ for $10 \mathrm{~min}$ for temperature equilibration. The mixture was mixed well again and kept at $37^{\circ} \mathrm{C}$ for $1 \mathrm{~h}$ for phase separations. The aqueous phase was removed gently to measure its absorbance $\left(\mathrm{A}_{0}\right)$ at $600 \mathrm{~nm}$ [9]. The hydrophobicity percentage was calculated as:

$$
\text { Hydrophobicity }(\%)=\left(1-\mathrm{A}_{1} / \mathrm{A}_{0}\right) \times 100
$$

\section{E. Haemolysis activity}

In haemolysis activity, all strains were spot-inoculated into sterile blood agar by adding $7 \%$ sheep blood into sterile blood agar base and incubated at $37{ }^{\circ} \mathrm{C}$ for $48 \mathrm{~h}$ [10]. The absence of clear zone surrounding the colonies indicates the good result for safety consumption of probiotic strains.

\section{Evaluation of antimicrobial activity of bioactive compound}

Antibacterial properties of both whole cell and their cell-free supernatant (CFSs) of probiotic Lactobacillus species have been evaluated by well diffusion method with slight modification. Overnight grown culture of all strains was inoculated in MRS broth and incubated for $18-20 \mathrm{~h}$ at $37^{\circ} \mathrm{C}$. The grown cultures were harvested by centrifugation at $10000 \mathrm{~g}$ for $10 \mathrm{~min}$ at $4{ }^{\circ} \mathrm{C}$ and $200 \mu \mathrm{l}$ cell-free supernatants were used for the assay. Antagonistic profile of bacterial isolates was studied in order to observe the inhibitory activity against standard pathogens such as E. coli MTCC82, Bacillus cerus ATCC10702, S. aureus MTCC96, S. typhyi MTCC3216, Aeromonas hydrophila ATCC7966 and Klebsiella pneumonia MTCC 109. Indicator strains of $300 \mu \mathrm{l}$ were mixed properly in $10 \mathrm{ml}$ of Luria Broth (LB) soft agar and overlaid on LB-base plate and leaving for solidification. After solidification, the holes were bored on a plate with the help of pipette tips $(200 \mu \mathrm{l}$, diameter $0.7 \mathrm{~cm})$. Then the holes were sealed by adding 1-2 drops of soft agar to avoid leakage of the supernatant. Then $100 \mu \mathrm{l}$ of prepared supernatant was added into each well and was kept in the fridge for $1-2 \mathrm{~h}$ for diffusion of the supernatant. The assay plates were incubated for $6-7 \mathrm{~h}$ at $37^{\circ} \mathrm{C}$. The zone of inhibition was measured with the help of zone measuring scale [8]. The same experiment was repeated three times.

\section{Physiological and biochemical identification of potent} antimicrobial strains

The most useful test for the determination of strain differences is carbohydrate fermentation. Eighteen different carbohydrates were used for identification. Again, gas production from glucose was assessed by inoculating the isolated strains in MRS broth containing glucose $(1 \%)$ containing Durham tube in inverted condition and incubated at $37{ }^{\circ} \mathrm{C}$ for $48-72 \mathrm{~h}$. The upward movement of inverted
Durham tube indicates positive reaction (gas production). Arginine hydrolysis test was another step to follow the identification procedure. The isolates which gave the bright orange were found to produce ammonia from arginine. The yellow color indicated negative arginine hydrolysis. Another criterion for the identification the isolates was the ability of growth at different temperatures and $\mathrm{NaCl}$ concentrations [11].

\section{Nature of antimicrobial compound}

Lactobacillus species produce lactic acid, proteins and $\mathrm{H}_{2} \mathrm{O}_{2}$ as an antimicrobial compound which can prevent the overgrowth of entering invasive pathogens. $100 \mu \mathrm{l}$ of supernatants buffered with $\mathrm{NaOH}(\mathrm{pH} 7.0)$ to neutralize acid effect while in a separate experiment, $75 \mu \mathrm{l}$ were mixed with catalase $(1.0 \%)$ to negate the effect $\mathrm{H}_{2} \mathrm{O}_{2}$. Then such prepared samples were placed into the well for evaluating nature of the compound. In other hand, culture supernatants were again treated with proteinase $\mathrm{K}$ to determine its proteinacious nature [12]. All samples were assayed for antimicrobial activity against same pathogens.

\section{Purification of antibacterial protein by column chromatography}

For purification of the antibacterial peptide, the collected supernatant was precipitated overnight with ammonium sulfate (40\%-95\%). The precipitate was collected by centrifugation at $12,000 \mathrm{rpm}$ for $20 \mathrm{~min}$ at $4{ }^{\circ} \mathrm{C}$. The precipitate was dissolved in a minimum volume of $50 \mathrm{mmol}$ PBS buffer and dialysed against the same buffer at $4{ }^{\circ} \mathrm{C} .5 \mathrm{ml}$ of the prepared peptide sample was loaded in a Sephadex (Sigma Aldrich, Germany) column $(1.0 \mathrm{~cm} \times 20 \mathrm{~cm}$ ) equilibrated with $1 \mathrm{X}$ PBS (pH 7.0) and eluted with a linear gradient of $\mathrm{NaCl}(0-1 \mathrm{M})$ in the same buffer at a flow rate of $60 \mathrm{ml} / \mathrm{h}$. All the fractions were collected and again subjected to antibacterial peptide assay $[12,13]$. The protein concentration $(\mathrm{mg} / \mathrm{ml})$ of the fraction showing antibacterial activity was estimated by using bovine serum albumin as the standard Lowry method [14] where its molecular weight was determined by sodium dodecyl sulfate-polyacrylamide gel electrophoresis.

\section{Stability of antimicrobial compound}

The stability of the purified antimicrobial compound was determined by exposing it to different ranges of temperature (60$\left.100{ }^{\circ} \mathrm{C}\right)$ and $\mathrm{pH}(2-10)$. To test heat sensitivity, the sample was treated to boiling temperature $\left(100^{\circ} \mathrm{C}, 30 \mathrm{~min}\right)$ in a water bath and evaluated its antimicrobial activity. In a separate experiment, it was re-suspended in 1:1 ratio of different buffer solutions ranging from $\mathrm{pH} 2.0-8.0$ to determine $\mathrm{pH}$ resistance capability of the purified antimicrobial compound [12].

\section{Statistical analysis}

The data recorded during the course of the investigation were subjected to significance testing using mean \pm standard deviation (SD) analysis. Statistical significance was set at $\mathrm{P}<0.05$. Results were denoted as mean \pm standard deviation (SD) of triplicate experiments

\section{RESULTS AND ANALYSIS}

\section{Identification of collected bacterial strains}

The primary identification (as per Bergey's Manual) of Lactobacillus species from collected dairy samples was mainly based on characteristics such as a gram positive rod, negative catalase, positive oxidase and non-spore formation. Gram staining followed by microscopic observation indicated that out of all bacterial isolates only 30 strains were Gram-positive, very small rods (cocobacilli) occurred singly or in pairs, non-spore forming and also catalase negative. They were again selected for probiotic activity evaluation along with Lactobacillus species directly collected from ATCC and MTCC.

\section{Probiotic evaluation}

\section{A. Acid and bile salt tolerance}

In general, acid and bile salt tolerance tests mainly indicate the survival potency of the strains in the gastrointestinal tract (GIT). In the present study, the viability of L. rhamnosus MTCC 1408, L. casei 
MTCC 1423 along with more four isolated Lactobacillus species (named as R1, R4, R7 and R18) in MRS broth have been observed in different $\mathrm{pH}$ values ( 2 and 3 ) and bile salt concentration $(0.3 \%$ and $0.6 \%$ ) till $2 \mathrm{~h}$. All the values were measured in the form of log $\mathrm{cfu} / \mathrm{ml}$ (fig. 1). The marginal reduction in the viability of the isolates indicated the excellent survival potency of the strain against physiological harsh conditions prevalent in the stomach like high acid and bile salt percentages. ANOVA test revealed that a highly significant variation of $\log \mathrm{CFU} / \mathrm{ml}$ values was observed among all the isolates $(\mathrm{P}<0.05)$.

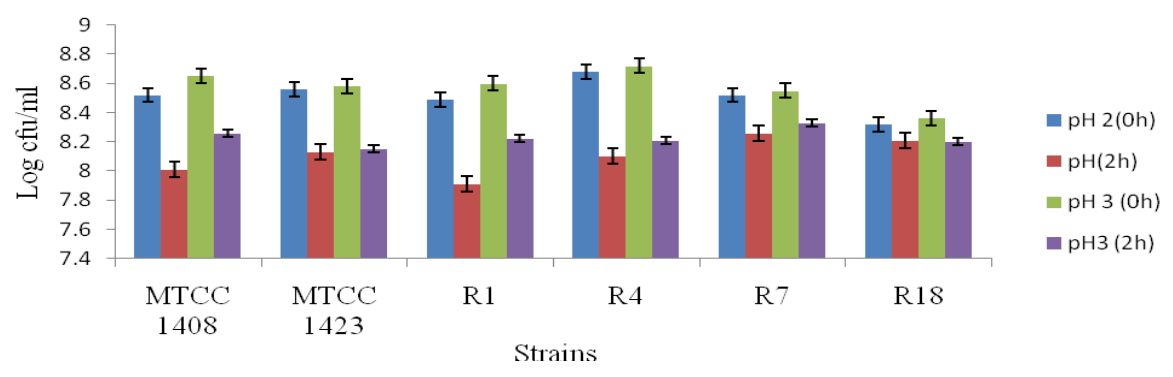

(a)

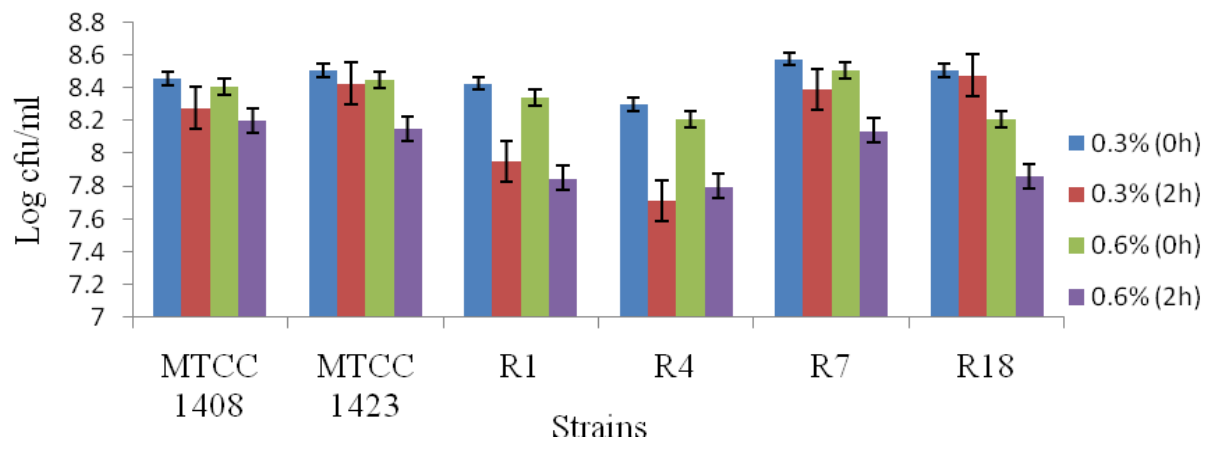

(b)

Fig. 1: (a) Viability $(\log \mathrm{cfu} / \mathrm{ml})$ of all probiotic strains with respect to $\mathrm{pH} 2-3$ till $2 \mathrm{~h}$, (b) viability (log cfu/ml) of same probiotic strains with respect to various bile salt conc. $(0.3,0.6 \%)$. The results are the means of 3 independent experiments and the bars correspond to standard deviations $(\mathrm{P}<0.05)$

\section{B. Bile salt hydrolase activity analysis}

Out all isolated and collected strains, the growth of only R1 and R7 along with a zone of salt precipitation around the colonies at the concentration of $5 \%$ could be observed on plates supplemented with sodium cholate. It suggested that R1 and R7 produced Bsh activity specific to bile salt (sodium cholate) hydrolysis.

\section{Cellular autoaggregation and cell surface hydrophobicity}

The auto-aggregation ability of the strains is one of the proposed mechanisms to explain the protective role of Lactobacilli where hydrophobicity may be playing a role in the cellular interaction. To evaluate the capability of strains to self-aggregate, the cellular autoaggregation were measured and under identical conditions only two strains, namely, L. casei MTCC 1423 (38.7\%) and R1 (46.5\%) showed maximum cell auto aggregation ability. Further study on cell surface hydrophobicity, adherence values of same two strains found to be highest out of all. Cell surface hydrophobicity of strains R1 and has been reported L. casei MTCC 1423 as high $75.25 \%$ and $65.853 \%$ respectively.

\section{Haemolysis activity for safety consumption}

No strain tested in this work exhibited $\alpha$-and $\beta$-hemolytic activity. The absence of clear zone around the strains indicates the safety consumption of probiotic.

\section{Antagonistic profile of bacterial strains}

After getting two potential probiotic strains (R1 and L. casei MTCC 1423), they were again screened for the release of antimicrobial bioactive compound that can inhibit the growth of large numbers of pathogenic bacteria like E. coli MTCC82, Bacillus cereus ATCC10702, S. aureus MTCC96, S. typhyi MTCC3216, Aeromonas hydrophila ATCC7966 and Klebsiella pneumonia MTCC 109. The culture supernatant prepared by using R1 showed highest antimicrobial activity against all pathogens except Aeromonas hydrophila ATCC7966. The diameters of inhibition zones observed in well diffusion method were greater than $10 \mathrm{~mm}$ (fig. 2). ANOVA test revealed that a highly significant variation of the zone of inhibition values was observed among all the isolates $(\mathrm{P}<0.05)$ against pathonens.

\section{Biochemical identification of Lactobacillus R1}

The potent probiotic Lactobacillus R1 gave positive test results with sugars, glucose, ribose, arabinose, trehalose, melibiose, raffinose, galactose, maltose, sucrose, fructose and lactose produced both gas from glucose and ammonia from arginine. It was resistant to $2 \%$ salt concentrations and grew at $45{ }^{\circ} \mathrm{C}$. When these biochemical test results are compared with the literature information [11], it seems that R1 is like to be Lactobacillus fermentum.

\section{Nature of antimicrobial compound}

The antimicrobial activity of culture supernatant of R1 was completely destroyed by proteinase $\mathrm{K}$ treatment. However, it was maintained after neutralization of acid and $\mathrm{H}_{2} \mathrm{O}_{2}$ which indicated that antibacterial activity was due to the activity of bacteriocin protein.

\section{Purification of antimicrobial milk bioactive peptide released by Lactobacillus $\mathbf{R 1}$}

All seven fractions (at different concentration of $\mathrm{NaCl}$ ) collected by performing column chromatography were checked for an antimicrobial activity where Elute 1 (by $0.01 \mathrm{~N} \mathrm{NaCl}$ ) demonstrated activity against indicator strains. Peptide concentration of the active fraction of R1 was found as 1.5 micrograms/ml by Lowry method. The molecular mass of the purified peptide fraction estimated from 
SDS-PAGE was approximately $25 \mathrm{kDa}$ which show a beneficial antagonistic effect against all tested pathogens.

\section{Effect of heat and pH treatment on stability}

The purified antimicrobial protein was considered to be heat stable, as there was no reduction in activity after heat treatment from 60 to $100{ }^{\circ} \mathrm{C}$ for 15 and $30 \mathrm{~min}$. Again, it was also found stable in the $\mathrm{pH}$ range of 4.5-7.0.

\section{DISCUSSION}

Several lactobacilli are known to have potential application as starters in food fermentation and have also been shown to exert a variety of positive health and nutritional effects $[8,9,13]$. The present investigation highlights the isolation, characterization and activity of the antimicrobial compound produced by L. fermentum R1 isolated from the dairy products to assess their anti-bacterial activity against some common pathogenic bacteria.

This study was performed with certain Lactobacillus strains directly collected from ATCC and MTCC and again, several dairy products (milk, yogurt, cheese) were collected from rural regions of Odisha for preliminary screening of more Lactobacillus strains. After gram staining the isolated bacteria were rod-shaped, smooth, shiny, irregular, circular, gram-positive, facultatively anaerobic, nonspore forming which indicate them to be the member of Lactobacillus.

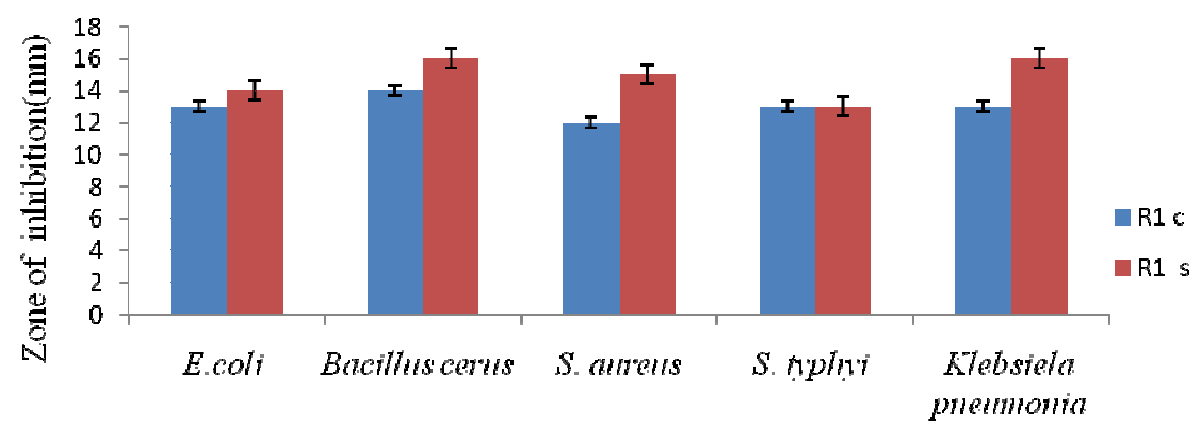

Pathogens

Fig. 2: Zones of inhibition shown by R1 culture (c) and its supernatant (s) against several pathogens. The results are the means of 3 independent experiments and the bars correspond to standard deviations $(\mathrm{P}<0.05)$

The result matched with Bergey's manual of systematic bacteriology. A similar result was also observed by $[13,1516]$ who isolated lactic acid bacteria (LAB) from dairy products. Probiotic microorganisms need to resist the adverse factors in the gastrointestinal tract, like the stomach acidity and bile salts excreted in the duodenum [17]. Here, probiotic attributes were evaluated based on two aspects, such as safety and functional. Again, functional criteria studies for successful probiotics mainly included survival, adherence, and colonisation while in vitro safety screenings of all isolated Lactobaciilus included haemolytic and gelatinase activities of the strains. Highly potent probiotic strains would have the ability to resist passage through the stomach in the presence of acid $(\mathrm{pH}$ ranges from 1.5 to 3 ) and most of the examined strains L. rhamnosus MTCC 1408, L. casei MTCC 1423 along with more four isolated Lactobacillus species (named as R1, R4, R7 and R18) were resistant to $\mathrm{pH} 3.0$ even after $2 \mathrm{~h}$ of exposure. These results are consistent with reports of the ability of lactobacilli to retain their viability when exposed to $\mathrm{pH}$ values of 1.5-3.0 [8, 9].

An efficient probiotic strain should be able to grow in bile salt with concentration ranging from $0.15-0.30 \%(\mathrm{w} / \mathrm{v})$ [18]. The isolated strains tolerated up to $0.6 \%$ which showed a good tolerance to bile salt. Bsh activity is a relevant property for probiotic strains to survive the toxicity of conjugated bile salts in the duodenum [19]. During the study, R1 and R7 produced Bsh activity specific to bile salt (sodium cholate) hydrolysis. A similar result was also observed by Pisano et al. (2014) [20] and Anas et al. (2014) [21] where they found deposition of sodium cholate indicate a positive result for Bsh activity. L. casei MTCC $1423(38.7 \%)$ and R1 (46.5\%) showed maximum cell autoaggregation ability while cell surface hydrophobicity of strains R1 and L. casei MTCC 1423 have been reported as high $75.25 \%$ and $65.853 \%$ respectively. In a previous study, the autoaggregation percentage of KSBT56 is $39.3 \%$ which was higher than LP9 (31.0), close to LA1 (40.4\%) but lower than other L. acidophilus i.e. LA7 (46.5\%) and LA14 (60.9\%). Again, the cell surface hydrophobicity of other standard probiotic strains (37.7\% to $58.3 \%$ in $n$-hexadecane and $37.1 \%$ to $60.8 \%$ in xylene for the standard strains) $[8,9]$. All LAB tested fulfilled the safety requirement that a probiotic strain should not have $\alpha$-and $\beta$ haemolytic activity. No strain tested in this work exhibited $\alpha$-and $\beta$ - hemolytic activity. Anas et al. (2014) [21] described the similar result in their study. Probiotics Lactobacillus spp are known to be inhibitory to the growth of a wide range of intestinal pathogens in human. Here, the antagonistic profile of all Lactobacillus spp. was studied in order to observe the inhibitory activity against standard pathogens such as E. coli MTCC82, Bacillus cerus ATCC10702, S. aureus MTCC96, S. typhyi MTCC3216, Aeromonas hydrophila ATCC7966 and Klebsiela pneumonia MTCC 109. The culture supernatant prepared by using R1 showed highest antimicrobial activity against all pathogens except Aeromonas hydrophila ATCC7966. The diameters of inhibition zones observed in well diffusion method were greater than $10 \mathrm{~mm}$. The same antimicrobial study was found in previous researches [13, 22, and 23] where Lactobacillus species were found to be effective against many grampositive and negative pathogens. The probiotic isolate exhibited the highest antibacterial activity chosen for its further characterization and analysis. The potent probiotic Lactobacillus R1 was identified as Lactobacillus fermentum by standard biochemical and physical characterizations (Bergey's manual 2nd edition), in agreement with other findings [11].

In other hand, culture supernatants were again treated with proteinase $\mathrm{K}$ to determine its proteinacious nature and could be purified by column chromatography. The antimicrobial activity of culture supernatant of R1 was completely destroyed by proteinase $\mathrm{K}$ treatment indicating its antibacterial activity was due to the activity of bacteriocin protein. The same observation was obtained in the literature [12] that supports the proteinacious nature of antimicrobial compound released from Lactobacillus fermentum R1. The compound responsible for this activity was identified as bacteriocin protein and was purified by column chromatography. Molecular weight of this antimicrobial protein is approximately 25 $\mathrm{kDa}$. Thus we believe that the compound secreted by R1 could release antimicrobial protein against a wide range of gram positive and gram negative pathogens and may be used as chemotherapeutic agent or biopreservatives. Similar studies were also observed by Ogunbanwo et al. (2003) [24] where the bacteriocin of L. plantarum F1 and $L$. brevis OG1 were recovered following the $60 \%$ saturation of the culture broths with ammonium sulphate with an increase to specific activity of 9.4 and $5.2 \mathrm{AU} / \mu \mathrm{g}$ protein respectively (Fraction 
1). The purified antimicrobial protein was found to be stable after heat treatment from 60 to $100{ }^{\circ} \mathrm{C}$ for 15 and $30 \mathrm{~min}$ and in the $\mathrm{pH}$ range of 4.5-7.0. Many researchers who were working on the field bacteriocin characterization found the same results in their studies $[12,24]$.

\section{CONCLUSION}

Though all isolated and collected Lactobacillus strains exhibit some good probiotic properties, only Lactobacillus fermentum R1 fulfills all the required criteria to be effective among all. It includes high viability to harsh conditions such as low $\mathrm{pH}$, high bile salt concentration, Bsh activity and a high percentage of adherence and colonisation. It can produce bacteriocin which inhibits a number of pathogenic organisms. In conclusion, the antimicrobial characteristics of Lactobacillus fermentum R1 indicates its possible use in starter cultures for traditional fermented foods as a means of improving the health condition. The partially purified inhibiting substance is most active at low $\mathrm{pH}$ values and retains its activity with an increase in temperature. This suits various food and pharmaceutical production processes.

\section{CONFLICT OF INTERESTS}

Declared none

\section{REFERENCES}

1. Vaughan E, Mollet B, de Vos WM. The functionality of probiotics and intestinal lactobacilli: light in the intestinal tract tunnel. Curr Opin Chem Biol 1999;10:505-10.

2. FAO/WHO. Guidelines for the evaluation of probiotics in foodjoint food and agricultural organisation of the United Nations and world health organization working group meeting report. London Ontario, Canada; 2002.

3. Tuomola E, Crittenden R, Playne M, Isolauri E, Salminen S. Quality assurance criteria for probiotic bacteria. Am J Clin Nutr 2001;73:393-8.

4. Gomes BC, Rodrigues MR, Winkelströter LK, Nomizo A, de Martinis EC. In vitro evaluation of the probiotic potential of bacteriocin producer Lactobacillus sakei. J Food Prot 2012;75:1083-9.

5. Gudina EJ, Teixeira JA, Rodrigues LR. Isolation and functional characterization of biosurfactant produced by Lactobacillus paracasei. Colloids Surf B 2010;76:298-04.

6. Nissen-Meyer J, Holo H, Havarstein LS, Sletten K, Nes IF. A novel lactococcal bacteriocin whose activity depends on the complementary action of two peptides. J Bacteriol 1992;174:5686-92.

7. De Vuyst L, Leroy F. Bacteriocins from lactic acid bacteria: production, purification, and food applications. J Mol Microbiol Biotechnol 2007;13:194-9.

8. Kaushik JK, Kumar A, Duary RK, Mohanty AK, Grover S, Vatish, VK. Functional and probiotic attributes of an indigenous isolate of Lactobacillus plantarum. PLoS One 2009. Doi:10.1371/ journal.pone.0008099.

9. Tripathy P, Suar M, Das JK, Saini M. Probiotic and functional characteristics of an indigenous lactobacillus species isolated from the traditional fermented product (Dahi-Chenna) of rural Odisha. Int J Curr Microbiol Appl Sci 2014;3:82-95.
10. Maragkoudakis PA, Konstantions CM, Psyrras D, Cremonese S, Fischer J, Cantor MD, et al. Functional properties of novel protective lactic acid bacteria and application in raw chicken meat against Listeria monocytogenes and Salmonella enteritidis. Int J Food Microbiol 2009;130:219-26.

11. Roos S, Engstrand L, Jonsson H. Lactobacillus gastricussp. nov., Lactobacillus antrisp. nov., Lactobacillus kalixensissp. nov. and Lactobacillus ultunensis sp. nov., isolated from human stomach mucosa. Int J Syst Evol Microbiol 2005;55:77-82.

12. Tiwari SK, Srivastava S. Characterization of a bacteriocin from lactobacillus plantarum strain LR/14. Food Biotechnol 2008;22:247-61.

13. Mohanty DP, Tripathy P, Mohapatra S, Samantaray DP. Bioactive potential assessment of antibacterial peptide produced by Lactobacillus isolated from milk and milk products. Int J Curr Microbiol Appl Sci 2014;3:372-80.

14. Lowry $\mathrm{OH}$, Rosebrough NJ, Farr AL, Randall RJ. Protein measurement with the Folin phenol reagent. J Biol Chem 1951;193:265-75.

15. Nes IF, Holo H. Class II antibacterial peptides from lactic acid bacteria. Biopolymers 2000;55:50-61.

16. Agrawal N, Prakash A. Isolation of lactic acid bacteria from fermented milk products and their antimicrobial activity against staphylococcus aureus. J Food Saf 2013;15:39-42.

17. Nowroozi J, Mirzaii M, Norouzi M. Study of lactobacillusas probiotic bacteria. Iran J Public Health 2004;33:1-7.

18. Suskovic J, Kos B, Matoic S, Besendorfer V. The effect of bile salts on survival and morphology of a potential probiotic strain Lactobacillus acidophilus M92. World J Microbiol Biotechnol 2000;16:673-78.

19. De Smet I, Van Hoorde L, Vande Woestyne M, Christiaens H, Verstraete W. Significance of bile salt hydrolytic activities of lactobacilli. J Appl Bacteriol 1995;79:292-301.

20. Pisano MB, Viale S, Conti S, Fadda ME. Preliminary evaluation of probiotic properties of lactobacillus strains isolated from sardinian dairy products. Biomed Res Int 2014. http://dx.doi.org/10.1155/2014/286390

21. Anas M, Ahmed K, Mebrouk K. Study of the antimicrobial and probiotic effect of lactobacillus plantarum isolated from raw goat's milk from the region of Western Algeria. Int J Sci: Basic Appl Res 2014;13:18-27.

22. Tharmaraj N, Shah NP. Antimicrobial effects of probiotics against selected pathogenic and spoilage bacteria in cheesebased dips. Int Food Res J 2009;16:261-76.

23. Sharafi H, Alidost L, Lababpour A, Zahiri HS. Antibacterial activity of probiotic lactobacillus plantarum HK01: effect of divalent metal cations and food additives on production efficiency of antibacterial compounds. Probiotics Antimicrob Proteins 2013. Doi:10.1007/s12602-013-9130-6.

24. Ogunbanwo ST, Sanni AI, Onilude AA. Characterization of a bacteriocin produced by Lactobacillus plantarum F1 and lactobacillus brevis OG1. Afr J Biotechnol 2003;2:219-27.

\section{How to cite this article}

- Debapriya Mohanty, Manish Ranjan Saini, Swati Mohapatra. In vitro study on the release of bioactive antimicrobial compounds from dairy products by certain promising probiotic Lactobacillus strains. Int J Pharm Pharm Sci 2017;9(4):27-31. 